\title{
Airway inflammation and the pathogenesis of asthma
}

\author{
PAUL M O'BYRNE MB FRCPI FRCPC \\ The Asthma Research Group, Department of Medicine, McMaster University, Hamilton, Ontario
}

PM O'BYRNE. Airway inflammation and the pathogenesis of asthma. Can Respir J 1994;1(3):189-195.

Airway inflimmation has been recognized for more than 100 years to be presient in the airways of patients with severe asthma. Much more recently, airwity inflammation has been identified to be central to the pathogenesis of all asthma. The inflammation is of a characteristic type, with the presence of activated eosinophils, mast cells and lymphocytes in bronchoalveolar lavage fluid and airway biopsies from patients with even mild asthma. Stimuli that are known to worsen asthma, such as inhaled allergens, also increase the nlumbers of mast cells and cosinophils in asthmatic airways. In addition, treatment with inhaled corticosteroids - the most effective treatment for asthma - improves symptoms and reduces the numbers of eosinophils, mast cells and lymphocytes in the airways. The precise functions of the cells in promoting inflammation and causing asthma symptoms has not yet been fully elucidated. However, it is very likely that eicosanoids, such as the cysteinyl leukotrienes, are produced by cosinophils and mast cells and are a major cause of bronchoconstriction in asthma. Also, these inflammatory cells can produce proinflammatory cytokines, such as granulocyte-macrophage colony-stimulating fictor. interleukin (IL) 3 and IL-5, which may promote continuing inflammation in the airways. Lastly, the persisting inflammatory cell infiltrate and products released from these cells are very likcly the cause of the airway structural changes characteristic of asthma, such as epithelial damage, goblet cell hyperplasia, smooth nuscle thickening and deposition of collagen below the basement membrane. These changes have been suggested to be the cause of airway hyperresponsiveness in asthma. An improved understanding of the precise mechanisms by which airway inflammation is initiated, propagates and causes airway damage will hopefully allow more precise treatment strategies to be developed for asthma than currently exist.

Key Words: Airway structural changes, Asthma, Cell mediators

\section{L'inflammation des voies aériennes et la pathogenèse de l'asthme}

RÉSUMÉ : L'inflammation des voies aériennes est connue depuis plus de 100 ans chez les patients souffrant d'asthme grave. Beaucoup plus récemment, cette inflammation a été identifiée comme le pivot de la pathogenèse de l'asthme. L'inllammation se caractérise par la présence d'éosinophiles ativés, de mastocytes et de lymphocytes dans le liquide provenant du lavage broncho-alvéolaire et des biopsies bronchiques de patients même atteints d'asthme bénin. Les stimuli connus pour aggraver l'asthme, comme les allergènes inhalés, augmentent aussi le nombre de mastocytes et d'éosinophiles dans les voies aériennes des asthmatiques. De plus, le traitement par corticostéroïdes inhalés, le plus efficace pour l'asthme, améliore les symptômes et réduit le nombre d'éosinophiles, de mastocytes et de lymphocytes dans les voies aériennes. Les fonctions précises des cellules qui déclenchent l'inflammation et qui causent les symptômes de l'asthme restent à élucider. Toutefois, il est fort probable que les éicosanö̈des tels que les leucotriènes cystéinylées sont produits par les éosinophiles et les mastocytes et qu'ils sont une cause majeure de bronchoconstriction dans l'asthme. De même, toutes ces cellules inflammatoires peuvent produire des cytokines pro-inflammatoires, telles que le facteur stimulant la production de lignées de granulocytes et de macrophages (GMCSF), l'interleukine-3 et l'interleukine-5 qui pourraient favoriser une inflammation bronchique chronique. Enfin, il se peut que la persistance d'un infiltrat cellulaire inflammatoire et de débris libérés par ces cellules causent les modifications structurales des voies aériennes typiques de l'asthme comme l'atteinte ípithéliale, l'hyperplasie des cellules caliciformes, l'épaississement du muscle lisse et l'accumulation de collagène sous la membrane basale. Ces modifications semblent indiquer qu'elles provoquent l'hyperréactivité bronchique associée à l'asthme. Une meilleure compréhension des mécanismes précis responsables du déclenchement de l'inflammation bronchique, de sa propagation et des lésions des voies aériennes permettra peut-être dans le futur de définir de nouvelles stratégies thérapeutiques contre l'asthme. 
$\mathrm{A}$ STHMATIC PATIENTS IISLIALI.Y PRESENT WITH CHARAC teristic symptoms, such as wheezing, cough, chest tightness and dyspnca, none of which are specific for asthma. A diagnosis of asthma is usually made by demonstration of reversible airway narrowing and/or airway hyperresponsiveness to a varicty of inhaled bronchoconstrictor stimuli (Figure 1) and by the response to appropriate treatment. Airway hyperresponsiveness is present in virtually all asthmatics with current symptoms (1): however, airway hyperresponsiveness is not specific for asthma and can be present in patients with other airway discases (2).

In 1892, William Osler published the medical texthook The Principuls and Practice of Medicine. In the chapter on asthma, Osler notes that "bronchial asthmaz ... in many cases is a special form of intlammation of the smaller bronchioles" (3). This reflected the then current descriptions of the pathology of the airways of patients dying of severe, fatal asthmat. A more complete description of airway inflammation in patients dying of acute asthma was provided by Dunnill and colleagues (4) in the 1960s. Thus, while atrway inflammation and its structural consequences had been recognized for more than 100 years. it was believed that inflammation was confined to the airways of asthmatic patients with very severe disease. More recently, the importanee of airway inflammation in the pathogenesis of asthma, ranging in severity from mild to severe, or in transient asthma after exposure to an inflammatory stimulus, has been recognized. This review examines the evidence that alrway inflammation is important in the pathogenesis of asthma, and considers the possible consequences of persisting airway inflammation on airwaty structure and function.

\section{AIRWAY INFLAMMATION IN ASTHMA}

Dorlands Medical Dictionary defines inflammation as the "condition into which tissues enter as a reaction to injury". A common manifestation of inllammation is the presence, at some time in the process, of activated inflammatory cells at the affected tissue site. The type of inflammatory cell varies with the type of inflammation. The most important inflammatory ecll at sites of acute inflammation is the neutrophil. However, in other, more chronic inflammatory conditions, cosinophils, lymphocytes or mast cells appear to be morc prominent. For the purposes of this article. airway inflammation is defined as the presence of activated inflammatory cells in the airways. While this definition is restrictive and excludes other important components of inllammatory events, such as edema and vasodilation, quantifying the numbers, and occasionally the state of activation, of inflammatory cells has been the most commonly used index of airway inflammation in studies of asthma.

Transient asthma and airway inflammation: The identilication ol stimuli that can cause transient asthma has proven to be important in studies of the pathogenesis of asthma. This is becausc the evidence that the presence of inflammatory cells is causally related to the development of airway hyperresponsiveness and transient asthma in human subjects initially depended on studics that examined numbers of cells

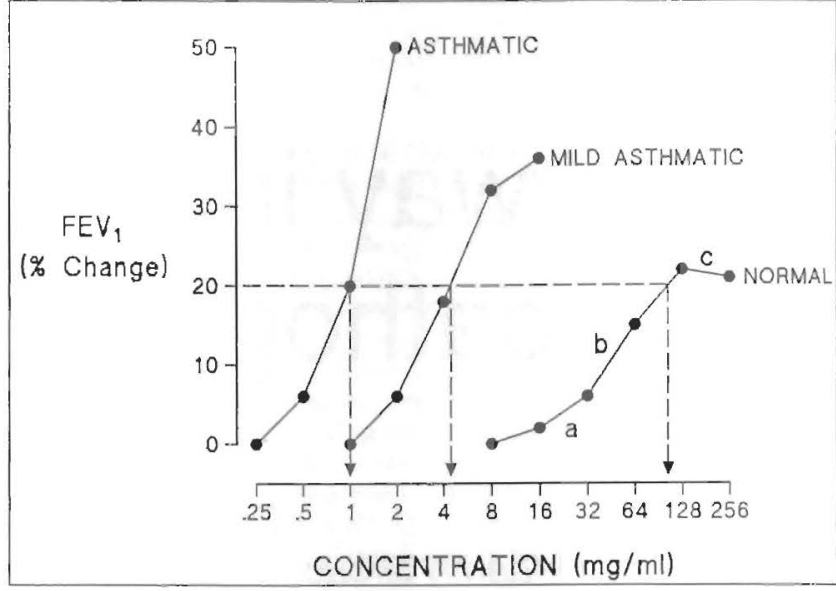

Figure 1) Airway responses to a bronchoconstrictor agonist in a normal subject, and subjects with mild and moderate asthma. Asthmatic airways are more sensitive to the agonist (a), have a steeper stope of the concentration response curve (b) and have a greater maximal response $(c)$

and cellular differentials in bronchoalveolar lavage fluid (BALF) before and after inhalation of ozone (5), the occupational sensitizing agents toluene diisocyanate (TDI) (6), and allergen (7), all of which are known to cause airway hyperresponsiveness and transient asthma or to exacerbate persisting asthma. These studies all demonstrated an acute inflammatory response in the airways associated with the development of variable airflow obstruction, airway hyperresponsiveness and asthma. In addition, the studies suggested that the stimulus which initiates the airway hyperresponsiveness determines the type of cellular response. For example, a substantial increase in neutrophils and a smaller increase in eosinophils were described in BALF in subjects with airway hyperresponsiveness following TDI (6). In contrast, airway challenge with plicatic acid, responsible for western red cedar asthma, caused increases in eosinophils, but not neutrophils in BALF (7). After allergen challenge, some studies describe increases in eosinophils (8), or eosinophils and neutrophils (9), or eosinophils, lymphocytes and basophils (10). Measurements in these studies were carried out at different lime points and with different challenge techniques, which may explain, in part, the varied results. However, it appears likely that different inhaled stimuli, such as allergen and TDI, cause a different pattern of cellular influx into BALF.

A more recent focus has been the examination of the state of activation of the inflammatory cells after allergen inhala. tion (11). These studies identified that eosinophils are activated, as indicated by positive staining for the marker for cosinophil cationic protein (EG2), as early as $3 \mathrm{~h}$ and persisted for more than $24 \mathrm{~h}$ in BALF after allergen inhalation, and this change preceded the increase in total number of eosinophils after allergen inhalation.

More recently, a less invasive method than bronchoscopy has been developed, using sputum induced by the inhalation of hypertonic saline, to quantify and characterize inflammatory cells in asthmatic airways. Studies using this method 
demonstrated that eosinophils increase markedly in sputum samples of asthmatics undergoing a naturally occurring exacerbation of their asthma (12), as well as $24 \mathrm{~h}$ after allergen inhalation, and persist for three days (13).

Persisting asthma and airway inflammation: A number of studies provided information on cell populations in BALF in mild stable asthmatics with persistent airway hyperresponsiveness and asthma (14-16). A common finding in all of these studies, as well as in recent examinations of bronchial mucosal biopsies $(17,18)$ is the presence of increased numbers of inflammatory cells, such as eosinophils, lymphocytes and mast cells, compared with normal control subjects with normal airway responsiveness. The eosinophils have shown signs of activation, as indicated by increased levels of granular proteins, major basic protein (15) and eosinophilic cationic protein (16). In the bronchial mucosa, the eosinophils have shown morphological features of activation, as indicated by heterogeneity of the granular structure (17) or as eosinophil granules lying free in the mucosal interstitium (17). Azzawi and colleagues (19) and Poston et al (20) have also demonstrated increased numbers of EG2-positive cells, as well as significant increases in activated $\mathrm{T}$ lymphocytes (19). Mast cells in the airway mucosa have exhibited various stages of degranulation (17) suggesting that mediator release is an ongoing process in the airways of stable asthmatics with persistent airway hyperresponsiveness.

Some studies have correlated numbers of inflammatory cells in BALF with the severity of methacholine airway hyperresponsiveness in stable asthmatics. Kirby et al (14) demonstrated close correlations between degree of airway hyperresponsiveness in subjects with mild asthma and number of mast cells and eosinophils in lavage fluid. Kelly and coworkers (21) showed correlations between numbers of neutrophils and airway hyperresponsiveness. They also found that the activity of both neutrophils and alveolar macrophages, as indicated by luminol-enhanced chemoluminescence, was increased in asthmatics compared with normal controls, demonstrating that these cells were metabolically active.

These studies can be summarized as demonstrating the presence of activated inflammatory cells, eosinophils, neutrophils, lymphocytes and mast cells in the airways of asthmatics, even at a time when they are considered stable and asymptomatic. The numbers of cells increase following a stimulus that causes airway hyperresponsiveness, as well as in natural exacerbations of asthma. However, the precise role of these different cells in causing airway hyperresponsiveness has not yet been clarified.

\section{INFLAMMATORY MEDIATORS AND ASTHMA}

Identifying a role for an inflammatory mediator in the pathogenesis of asthma has relied on the collection of various types of evidence. Generally, when the structure of the mediator is identified and synthesized, the mediator is given (usually by inhalation) to asthmatics to identify whether it can mimic some component of the asthmatic response. Subsequently, when assays for its measurement are available, efforts are made to measure the mediator or its metabolite during asthmatic responses. When antagonists for the mediator or inhibitors of its synthesis are available, they are studied in clinical models of asthma. The final, and most difficult, hurdle is to determine whether the mediator antagonists or synthesase inhibitors are useful in treating asthmatic patients. A variety of mediators has been suggested to be important in the pathogenesis of asthma. These have included histamine, acetylcholine, prostaglandins $\mathrm{D}_{2}$, and $\mathrm{F}_{2} \alpha$, thromboxane, cysteinyl leukotrienes, platelet activating factor, and, most recently, cytokines and growth factors.

Histamine and acetylcholine: Histamine and acetylcholine have biological effects relevant to asthma; both are released in response to appropriate stimuli - acetylcholine from airway nerves and histamine from airway mast cells; both are potent bronchoconstrictors, and histamine has other effects such as vasodilation and increasing vascular permeability. In addition, $H_{1}$ receptor antagonists have been demonstrated to inhibit partially some asthmatic responses, such as exerciseinduced bronchoconstriction (22). However, even very potent and long acting antihistamines are not effective bronchodilators, nor do they have a useful role in the management of asthma. Atropine and other anticholinergics, such as ipratropium bromide, are bronchodilators and have been used for many years to treat bronchoconstriction, and, more recently, to treat (together with inhaled $\beta_{2}$-agonists) acute severe asthma (23). This suggests that acetylcholine is released from airway nerves in asthmatics and causes bronchoconstriction. However, anticholinergics do not modify any other important component of asthma, which indicates that acetylcholine release is not involved in the underlying pathogenesis of asthma.

Thromboxane: Thromboxane $\mathrm{A}_{2}$ is a potent constrictor of smooth muscle, and its analog, U46619, constricts human airways (24). A recent study examining the effects of a thromboxane synthetase inhibitor on airway responses after allergen challenge demonstrated slight, but significant, inhibition of the allergen-induced early asthmatic responses by 20 to $25 \%$, but no inhibition of allergen-induced late asth matic responses and allergen-induced histamine airway hyperresponsiveness $24 \mathrm{~h}$ post-allergen (25). This suggested that thromboxane may be released following allergen chal lenge and may be partly responsible for the early asthmatic response, but is not important in causing other allergeninduced responses. The thromboxane $\mathrm{A}_{2}$ synthetase inhibitor, OKY 046, administered orally, has been shown to improve acetylcholine airway hyperresponsiveness in stable asthmatic subjects (26). However, these studies were uncontrolled and need to be repeated in a placebo controlled double-blind study before the results can be properly interpreted. There are no published studies on the clinical efficacy of thromboxane receptor antagonists or synthetase inhibitors in the management of asthma. However, the weak activity in protecting against allergen-induced asthmatic responses suggests that these compounds are unlikely to have a major clinical effect.

Platelet activating factor: Platelet activating factor (PAF) has a variety of actions, which includes the recruitment and 


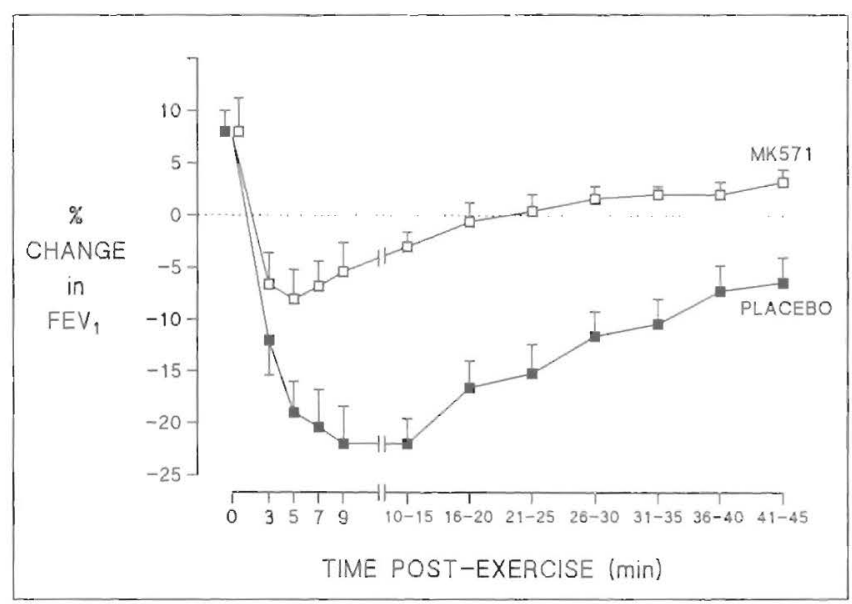

Figure 2) Percentage (hange in forced expiratory volume (FEV), (mean and SEM) over time post-exercise following treatment with

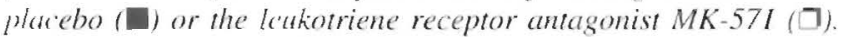
Treatment with $M K-57 I$ significanty reduced the maximal fall in $F E V_{1}$ affer exercise $(P<0.00 I)$ and shortened the recovery time $(P<0.001)$. (Reproduced with permission from reference 39)

activation of inflammatory cells, particularly eosinophils and neutrophils (27). Inhaled PAF has also been described ats causing bronchoconstriction and airway hyperresponsiveness in normal subjects in some (28), but not other (29), studies. PAF has also been demonstrated to be released into the plasma following allergen inhalation in mild asthmatic subjects (30). For these reasons, PAF has been suggested 10 be an important mediator in the development of allergeninduced late asthmatic responses and alirway hyperresponsiveness, and was suggested to play an important role in the ongoing airway inflammation of asthma.

A variety of very potent and selective PAF receptor antagonists has become availatble lor clinical study. Until recently, the 'gold standard' compound has been the thieno-triazolodiazepine, WEB 2086. This compound has been used to characterize the PAF receptor, and has been shown to prevent PAF-induced bronchoconstriction in human subjects (31). Rccent studics have demonstrated that WEB 2086, or another very potent PAF antagonist, UK 74,505 , was completely ineffective in inhibiting allergeninduced early or late asthmatic responses or allergen-induced airway hyperresponsiveness $(32,33)$. Thus, PAF does not appear to be important in the pathogenesis of allergen responses in asthma. It is very unlikely that oral PAF antagonists will have clinical efficacy in asthma, although high concentrations delivered topically by inhalation may be more effective.

Cysteinyl leukotrienes: Cysteinyl leukotrienes (LT) $\mathrm{C}_{4}$ and $\mathrm{D}_{4}$ are the most potent bronchoconstrictors yet studied in human subjects, are up to 10,000 times more potent than methacholine in some normal subjects (34), and have a longer duration of action than inhaled histamine (35). Increases in urinary levels of $\mathrm{LTE}_{4}$, the metabolite of $\mathrm{LTC}_{4}$ and $\mathrm{LTD}_{4}$, have been demonstrated following allergen-induced early responses $(36,37)$, in patients presenting to hospital with acute severe asthma (37) and following exerciseinduced bronchoconstriction (38). Studies with potent and specific leukotriene antagonists have supported an important role for the leukotrienes in clinical models of asthma, such as exercise (39) (Figure 2), and allergen- (40) and acetylsalicylic acid-induced asthma (41). Leukotriene release is partly responsible for spontaneous bronchoconstriction in asthma (42). Recent studies have suggested that the cysteinyl leukotrienes can also cause the release of inhibitory prostaglandins in asthmatic airways, which probably is the cause of exercise refractoriness (reduced bronchoconstriction with repeated exercise challenges) in asthmatic subjects (43). Lastly, the initial studies of the leukotriene antagonists and synthesis inhibitors have demonstrated clinical efficacy in asthma (44). These results taken together indicate that the cysteinyl leukotrienes are important in the pathogenesis of asthma.

Cytokines: More than 30 different protein mediators are classed as cytokines. Some of these have been implicated in the pathogenesis of asthma, mainly because of the ability of some of these proteins to promote inflammatory cell growth and differentiation, or inflammatory cell migration and activation, or they may cause changes in the structural cells of the airways. The study of the cytokines in asthma is not yet as developed as for the lipid mediators, mainly because of the lack of specific antagonists that can be studied in humans. However, the cytokines interleukin-3, interleukin-5, and granulocyte macrophage-colony stimulating factor (GMCSF) may be important because of their ability to promote eosinophil differentiation, recruitment and activation into the airways, and prolong the survival of these cells once in the airways. All of these cytokines, as well as interleukin-4. which is necessary for immunoglobulin E production, are produced by one type of helper $\mathrm{T}$ cell, the $\mathrm{TH}_{2}$ cell, which is present in asthmatic airways (45). In addition, other airway cells may be responsible for the production of these cytokines. Increased amounts of GM-CSF are present in airway biopsies from mild asthmatics, and the levels increase after allergen challenge $(46,47)$. It appears very likely that these, as well as other cytokines, are responsible for the presence of persisting activated eosinophils and mast cells in asthmatic airways; however, further studies with drugs that block the action of specific cytokines will be needed to establish precisely their role in asthma.

\section{AIRWAY STRUCTURAL CHANGES IN ASTHMA}

Several structural changes have been described in asthmatic airways, which appear to be characteristic of the disease and which may also be responsible for the presence of persisting airway hyperresponsiveness in asthma. These changes include: patchy desquamated epithelium; thickening of the reticular collagen layer below the basement membrane; and airway smooth muscle hypertrophy. Both epithelial damage and smooth muscle hypertrophy have been implicated in the pathogenesis of airway hyperresponsiveness in asthma.

Airway epithelial damage: Epithelial damage and desquamation are present in airways of patients with asthma 
(48). Onc hypothesis to explain epithelial damage and desquamation in asthmatic airways is that basic protcins released from activated eosinophils damage the epithelium. Levels of major basic protein have been shown to be increased in BALF from asthmatic patients (15). Major basic protein has also been identified in tissue sections by means of immunofluorescence from airways of patients dying from severe asthma (4)). Even in sections where identifiable eosinophils could not be seen, evidence showed major basic protein to be present in epithelium and submucosa giving signs of tissue damage (49).

Several hypotheses have been proposed to explain how epithelial damage may result in airway hyperresponsiveness in asthma. These include increased permeability of the airway epithelium; loss of inhibitory mediators generated by the airway epithelium; and luss of neutral endopeptidase. Several studies compared the permeability of the respiratory epithelium in normal subjects, asthmatics and asymptomatic smokers. These sudien demonstrated that the clearance of inhaled radiolabelled aerosols from the lung into the blood was much faster in asymptomatic smokers with normal airway responsiveness than in either normal subjects with normal airway responsiveness or in asthmatic subjects with airway hyperresponsiveness $(50)$. These results make it very unlikely that increases in airway epithelial permeability are the cause of airway hyperresponsiveness in isthma.

The epithelium has been reported to release a fiactor that reduces the airway smooth muscle contractile responses to agonists such as histamine and acetylcholine (51). This mediator has been called epithelium-derived relaxing factor (EpDRF). The hypothesis that loss of an inhibitory EpDRF may be responsible for airway hyperresponsiveness in asthma has not been possible to test in human subjects. Studies in dogs demonstrated that the function of EPDRF in vitro, as decrmined by the ability to reduce the contractile responses of the trachealis to acetylcholine, histamine or serotonin, was unaltered in dogs with airway hyperresponsiveness in vivo compured with control dogs (52). It is unlikely, therefore, that Ioss of EpDRF is the cause of arwaly hyperresponsiveness, al least in this animal preparation.

Airway epithelial cells are known to release prostaglandin $\mathrm{E}_{2}$ (53), which has potent inhibitory effects in the airways. such as presynaptic modulation and inhibition of acetylcholine release from muscarinic nerves (54). In addition, prostaglandin $\mathrm{E}$ has been shown 10 reduce contractile responses to inhaled histamine, acelylcholine and methat choline (5.5), as well as bronchoconstrictor responses to exercise in atshmatics (56). The airway cpithelium also contains enzymes - neutral cndopeptidases c. capable of metabolizing tachykinins such as substance $P$ (57), which are bronchoconstrictor and prointlammatory mediators. Loss of these inhibitory mediators may have important results in asthmatic airways; however, this hypothesis has not yet been tested in asthmatic subjects.

Airway smooth muscle: Airway hyperresponsiveness in asthma is nonspecific. This means that asthmatic airways are more responsive to all bronchoconstrictor mediators acting on airway smooth muscle receptors. One explanation lor the lack of specificity is that the underlying abnormality in asthmatic airways resides in the smooth muscle. The responses of airway smooth muscle from human subjects with airway hyperresponsiveness in vivo have been studied by a number of different investigators $(58,59)$. No comsistent increase in smooth muscle responsiveness in vitro has been associated with airwatys hyperresponsiveness in vivo. Very lew studies have examined smooth muscle in vitro from subjects with airway hyperresponsiveness and asthma. A small number ol studies of airway smooth muscle from asthmatic subjects suggest that the smooth muscle is hyperresponsive to agonists in vitro compared with airways from nonasthmatic subjects $(00,61)$. Thus, an inherent defect may exist in asthmatic airway smooth muscle, which accounts for airwaly hyperresponsiveness.

Another possibility by which the increase in airway smooth muscle volume in asthmatics causes airway hyperresponsiveness is by ciusing thickening of asthmatic airways. James et al (62), using modelling studies, demonstrated that a small increase in the thickness of the airway wall, which is not possible to demonstrate by changes in spiromeric indexes, could result in airway hyperresponsiveness in asthmit.

\section{CONCLUSIONS}

Airway inflammation appears to be central to the pathogenesis of all of the clinical manifestations of asthma. Many studies have now demonstrated the presence of activated eosinophils and mast cells in the airway lumen and airway wall of patients with asthma, even those with mild disease. The presence and survival of these inflammatory cells may be promoted by increased proinflammatory cytokines, such as GM-CSF, in asthmatic airways. These cells have the capacity to release potent bronchoconstrictor mediators such as the cysteinyl leukotricnes, which are responsible, in part at kast, for airway narrowing in asthma and for allergen, exercisc and acetylsalicylic acid-induced asthma. Other cells, such as a subset of $\mathrm{T}$ lymphocytes $\left(\mathrm{TH}_{2}\right)$, may also be important in maintaining the inflammatory cascade. Airway structural changes caused by persisting inflammation, such at airway epithelial damage, or altered smooth muscle function or volume. are likely to be important in the pathogenesis of stable long standing airway hyperresponsiveness. Mediators released from the inflammatory cells may be responsible for these changes. Despite the great increase in knowledge ahout airway inflammation in the pathogenesis of asthma, the sequence of events leading to the presence of persisting airway inflammatory cells, airway structural changes and airway hyperresponsiveness in asthma remains 10 be clarilicd.

\section{REFERENCES}

1. Cockcroft DW, Killian DN, Mellon JJA, Hargreave FE. Bronchial reactivity of inhaled histamine: a method and clinical survey. Clin Allergy 1977;7:235-43.

2. Ramsdale EH, Morris MM, Roberts RS, Hargreave FE. Bronchial responsiveness to methacholine in chronic bronchitis: relationship to airflow obstruction and cold air 
responsiveness. Thoratx 1984;39:(912-8.

3. Osler W. The Principals and Practice of Medicine. New York: Appleton and Co, 1892:497.

4. Dunnill MS, Massarell GR, Anderson JA. A comparison of the quantitive anatomy of the bronchi in normal subjects, in status asthmaticus, in chronic bronchitis and in emphysema. Thorax 1969;24:176-9.

5. Stelzer J, Bigby BG, Stulbarg M, et al. Ozone-induced changes in bronchial reactivity to methacholine and airway inflammation in humans. J Appl Physiol 1986:60:1231-326.

o. Fabbri LM, Boschetto P, Zocca E, et al. Bronchoalveolar neutrophilial during late asthmatic reactions induced by toluene diisocyanalc. Am Rev Respir Dis 1987;136:36-42.

7. Lam S. Chan-Yeung M, Le Riche J, Kijek K, Phillip D. Cellular changes in bronchial lavage fluid following late asthmatic reactions in patients with red cedar asthma. J Allergy Clin Immunol 1987:80:44-50.

8. DeMonchy JGR, Kauffman HF, Venge P, clat. Bronchoalveolar eosinophilia during allergen-induced late asthmatic reaction. Am Rev Respir Dis 1985;131:373-6.

9. Metzger WJ, Zavala D, Richerson HB, et al. Local allergen challenge and bronchoalveolar lavage of allergic asthmatic Iungs. Am Rev Respir Dis 1987:135:433-40.

10. Diaz P, Gonzalez MC, Galleguillos FR, et al. Leucocytes and mediators in bronchoalveolar lavage during allergen-induced Iate-phase asthmatic reactions. Am Rev Respir Dis 1989;139:1383-9.

11. Aalbers R, Kauffman HK, Vrugt B, et al. Bronchial Iavage and bronchoalveolar lavage in allergen-induced single early and dual asthmatic responses. Am Rev Respir Dis 1993:147:76-81.

I.2. Gibson PG, Girgis-Gabardo A, Hargreave FE, et ill. Cellular characteristics of sputum from patients with asthmit and chronic bronchitis. Thorax 1989;44:693-9.

13. Pin I, Freitag AP, O'Byrne PM, et al. Changes in the cellular profile of induced-sputum after allergen-induced asthmatic responses. Am Rev Respir Dis 1992; I45: 1265-9.

14. Kirby JG, Hargreave FE, Gleich GJ, O’Byrne PM. Bronchoalveolar cell profiles of asthmatic and nonasthmatic subjects. Am Rev Respir Dis 1987;136:379-83.

15. Wardlaw AJ, Dunnette S, Gleich GJ, Collins JV, Kay AB. Eosinophils and mast cells in bronchoalveolar lavage in subjects with mild asthma. Am Rev Respir Dis 1988;137:62-9.

16. Ädelroth E, Rosenhall L, Johansson SÅ, Linden M, Venge P. Inflammatory cells and eosinophilic activity in asthmatics investigated by bronchoalveolar lavage: the effects of anti-asthmatic treatment with budesonide or terbutaline. Am Rev Respir Dis 1990; 142;9 [-9.

17. Beasley R, Roche WR, Robents JA, Flolgate ST. Collulu events in the bronchi in mild asthma and after bronchial provocation. Am Rev Respir Dis 1989;139:806-17.

18. Jeffery PK. Wardlaw AJ, Nelson F, Collins JV, Kay AB. Bronchial biopsies in asthma. An ultrastructural, quantitative study and correlation with hyperreactivity. Am Rev Respir Dis 1989;140:1745-53.

19. Azzawi M, Bradley B, Jeffery PK, et al. Identification of activated $\mathrm{T}$-lymphocytes and eosinophils in bronchial biopsies in stable atopic asthma. Am Rev Respir Dis 1990;142:1407-13.

20. Poston RN, Chanez P, Lacoste JY, Litchfield T, Lee TH, Bousquet J. Immunohistochemical characterization of the cellular infiltration in asthmatic bronchi. Am Rev Respir Dis 1992;145:918-2I.

21. Kelly C, Ward C, Stenton CS, Bird G, Hendrick PJ, Walters EH. Number and activity of inflammatory cells in bronchoalveolar lavage fluid in asthma and their relation to airway hyperresponsiveness. Thorax 1988;43:684-92.

22. Hartley JPR, Nogrady SG. Effect of an inhaled antihistamine on exercise-induced asthma. Thorax 1980;35:675-9.

23. Rebuck AS, Chapman KR, Abboud R, et al. Nebulized anticholinergic and sympathomimetic treatment of asthma and chronic obstructive airways disease in the emergency room. Am J Med 1987:82:59-64.

24. Jones GL, Saroea G, Watson RL, O'Byrne PM. The effect of an inhaled thromboxane mimetic (U46619) on airway function in human subjects. Am Rev Respir Dis 1992;145:1270-5.

25. Manning PJ, Stevens WH, Cockcroft DW, O'Byrne PM. The role of thromboxane in allergen-induced asthmatic responses. Eur Respir J 199I;4:667-72.

26. Fujimura M, Sasaki F, Nakatsumi Y, et al. Effects of a thromboxane synthetase inhibitor (OKY-046) and a lipoxygenase inhibitor (AA-861) on bronchial responsiveness to acetylcholine in asthmatic subjects. Thorax 1986;41:955-9.

27. Barnes PJ, Chung KF, Page CP. Platelet activating factor as a mediator of allergic disease. J Allergy Clin Immunol 1987;81:919-34.

28. Cuss FM, Dixon CMS, Barnes PJ. Effects of inhaled platelet activating factor on pulmonary function and bronchial responsiveness in man. Lancet 1986; ii:189-92.

29. Lai CK, Jenkins JR, Polosa R, Holgate ST. Inhaled PAF fails to induce airway hyperresponsiveness to methacholine in normal human subjects. J Appl Physiol 1990;68:919-26.

30. Chan-Yeung M, Lam S, Chan H, Tse KS, Salari H. The release of platelet-activating factor into plasma during allergen-induced bronchoconstriction. J Allergy Clin Immunol 1991;87:667-73.

31. Adamus WS, Heuer HO, Meade CJ, Schilling JC. Inhibitury effects of a new PAF acether antagonist WEB 2086 on pharmacologic changes induced by PAF inhalation in human beings. Clin Pharmacol Ther 1990;47:456-62.

32. Freitag A, Watson RW, Matsos G, Eastwood C, O'Byrne PM. The effect of a platelet activating factor antagonist, WEB 2086 , on allergen-induced asthmatic responses. Thorax 1993;48:594-8.

33. Kuitert LM, Hui KP, Uthayarkumar S, et al. Effect of a platelet activating factor antagonist, UK 74,505, on early and late responses to allergen. Am Rev Respir Dis 1993;147:82-6.

34. Adelroth E, Morris MM, Hargreave FE, O'Byrne PM. Airwaly responsiveness to leukotrienes $\mathrm{C} 4$ and $\mathrm{D} 4$ and to methacholine in patients with asthma and normal controls. N Engl J Med 1986;315:480-4.

35. Barnes NC, Piper PJ, Costello JF. Comparative effects of inhaled leukotriene $\mathrm{C} 4$, leukotriene D4 and histamine in normal human subjects. Thorax 1984;39:500-4.

36. Manning PJ, Rokach J, Malo JL, et al. Urinary leukotriene $\mathrm{E}_{4}$ levels during early and late asthmatic responses. I Allergy Clin Immunol 1990;86:21 1-20.

37. Taylor GW, Black P, Turner N, et al. Urinary leukotrienc Jif after antigen challenge and in acute asthma and allergic rhinitis. Lancet 1989;i:584-7.

38. Kikawa Y, Miyanomae T, Inoue Y, et al. Urinary leukotriene $\mathrm{E}_{4}$ after exercise challenge in children with asthma. J Allergy Clin Immunol 1992;89:1111-9.

39. Manning PJ, Watson RM, Margolskee DJ, Williams V, Schartz JI, O'Byrne PM. Inhibition of exercise-induced bronchoconstriction by MK-571, a potent leukotriene $\mathrm{D}_{4}$ receptor antagonist. N Engl J Med 1990;323:1736-9.

40. Taylor IK, O'Shaughnessy KM, Fuller RW, Dollery CT. Effect of a cysteinylleukotriene receptor antagonist, ICI 204-219 on allergen-induced bronchoconstriction and airway hyperreactivity in atopic subjects. Lancet 1991;337:690-4.

41. Dahlen B, Kumlin M, Margolskee DM, et al. The leukotriene-receptor antagonist MK-0679 blocks airway obstruction induced by inhaled lysine aspirin in aspirin-sensitive asthmatics. Eur Respir J 1993;6:1018-26.

42. Gaddy J, Bush RK, Margolskee D, Williams VC, Busse W The effects of a leukotriene $\mathrm{D}_{4}\left(\mathrm{LTD}_{4}\right)$ antagonist (MK-571) in mild to moderate asthma. Am Rev Respir Dis 1992;146:358-63. 
43. Manning [PJ, Watson RW. O'Byrne PM. Exercisc-induced refractoriness in asthmatic subjects involves leukotrienc and prostaglandin interdependent mechanisms. Am Rev Respil Dis 1993; 148:950-4.

44. Israel E, Rubin P, Kemp JP, ct all. The effect of inhibition of 5-lipoxygenase by zilcuton in mild-to-moderate asthma, Ann Intern Med 1993;1 19:1059-60.

45. Robinson DS, Hamid Q. Ying S, ct al. Predominent TH2-like bronchoalveolar T-Iynphocy te populations in atopic asthmil. N Engl J Med 1992;326:298-304.

46. Woolley KL, Adelroth E, Woolley MJ, Ellis R, Jordana M, O’Byrne PM. Granulocyte-macrophage colony-stimulating factor, eosinophils and eosinophil cationic protein in mild asthmatics and non-asthmatics. Eur Respir J. (In press)

47. Sousa AR, Poston RN, Lane SJ, Nakhosteen JA, Lee TH. Detection of GM-CSF in asthmatic bronchial epithelium and decrease by inhaled corticosteriods. Am Rev Respir Dis 1993:147:1557-61

48. Laitinen LA, Huino M, Laitmen $A$, Kilva T, Haahteli $T$. Damage of the airway cpithelium and bronchial reactivity in patients with asthma. An Rev Respir Dis 1985:131:599-60).

49. Gleich GJ, Adolphson (R. Leiferman KM. The biology of the eosinophilic leukocyte. Ann Rev Med 1993;44:85-92.

50. O’Byrne PM, Dolovich M, Dirhs R, Roberts RS, Newhousc MT. Lung epithelial permeability: Relation to nonspecific airway responsiveness. J Appl Physiol 1984:57:77-84.

51. Flavahan NA, Aarhuus LL, Rimele TJ, Vanhoutte PM. Respiratory epithelium inhibits bronchial smooth muscic tonc. J Appl Physiol 1985;58:834-8.

52. Jones GL, Lane CG, O’Byrne PM. Releilsc of epithelium-derived relixation factor (LPDRF). J Appl Physiol 1988;65:1238-43.
53. Loikatu (iD), (Ghi IF, Nadel JA, Widdicombe JH. Bradykinin stimulates $\mathrm{Cl}$ secretion and prostaglandin E2 release by cimninc tracheal epithelium. Am J Physiol 1985;248:F48-55.

54. Walters EH, O’Byrne PM, Fabbri LM, Graf PD, Holtzman MJ, Nadel JA. Control of neurotransmission by prostaglandins in canine trachealis smooth muscle. J Appl Physiol 1984;57:129-34.

55. Manning PJ, Lane CG, O'Byrne PM. The effect of oral prostaglandin $\mathrm{E}_{1}$ on airway responsiveness in asthmatic subjects. Pulm Pharmacol 1989;2:12 I-4.

56. Melillo E, Woolley KL, Manning PJ, Watson RM, O'By rnc PM. Effect of inhaled $\mathrm{PGE}_{2}$ on exercise-induced bronchoconstriction in asthmatic subjects. J Respir Crit Care Med. (In press)

57. Dusser DJ, Jacoby DB, Djokic TD, Rubinstein I, Borsun DB, Nadel JA. Virus induces airway hyperresponsiveness to tachykinins: role of ncutral endopeptidase. I Appl Physiol 1989:67:150)-11

58. Vincenc CS, Black JL, Yan K, et al. Comparison of in vivo and in vitro responses to histamine in human airways. Am Rev Respir Dis 1983;128:875-9.

59. Roberts JA, Raeburn D, Rodger IW, Thomson NC. Comparison of in vivo airway responsiveness and in vitro smooth muscle sensitivity to methacholine in man. Thorax I 984;39:837-43.

60. Schellenberg RR, Foster A. In vitro responses of human asthmatic airway and pulmonary vascular smooth muscle. Int Arch Allergy Appl Immunol 1984;75:237-4I.

6). Bai TR. Abnormalities in airway smooth muscle in fatal asthma. Am Rev Respir Dis 1990; 141:552-7.

62. James Al, Pare PD, Hogg JC. The mechanics of airway n:urowing in asthma. Am Rev Respir Dis 1989;139:242-6. 


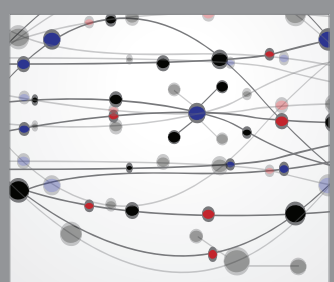

The Scientific World Journal
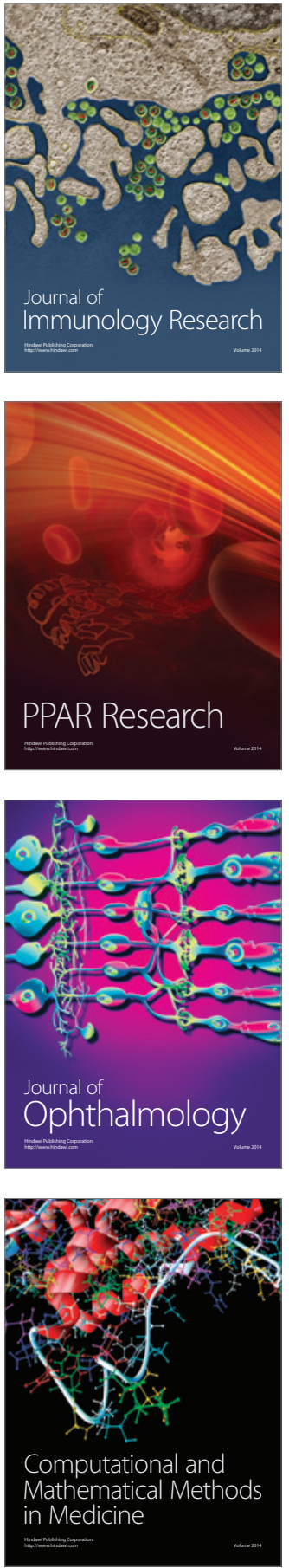

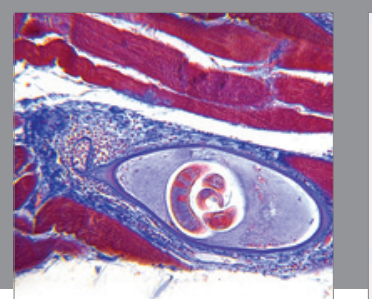

Gastroenterology Research and Practice

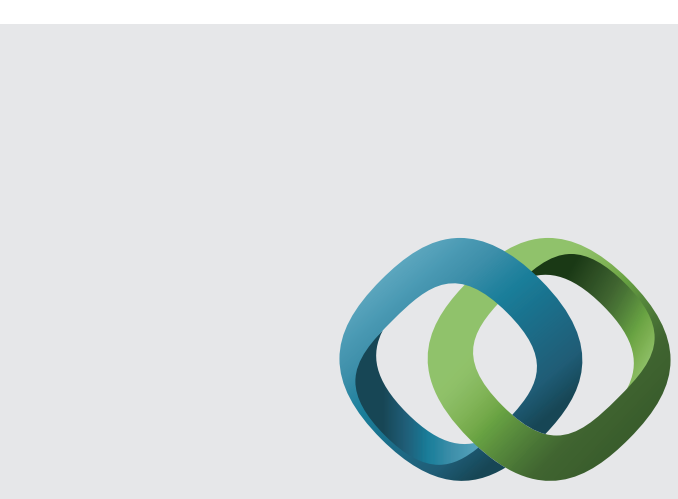

\section{Hindawi}

Submit your manuscripts at

http://www.hindawi.com
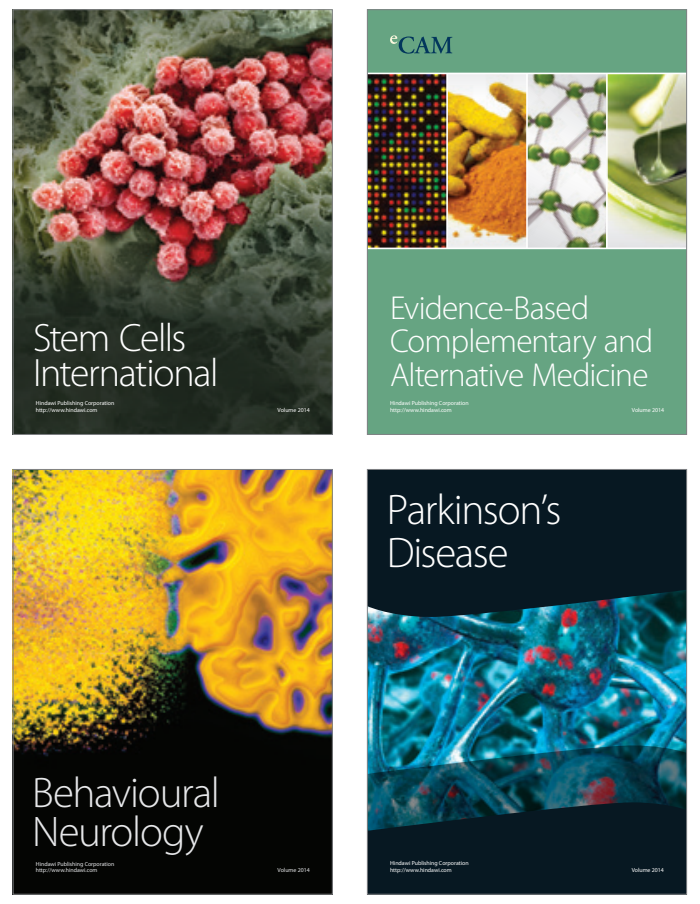
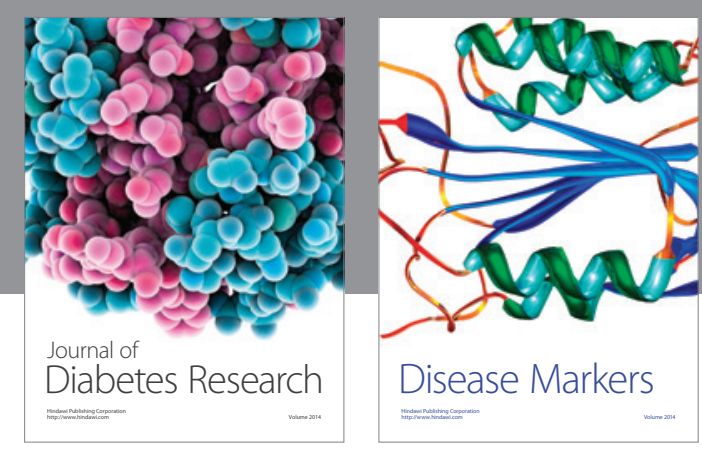

Disease Markers
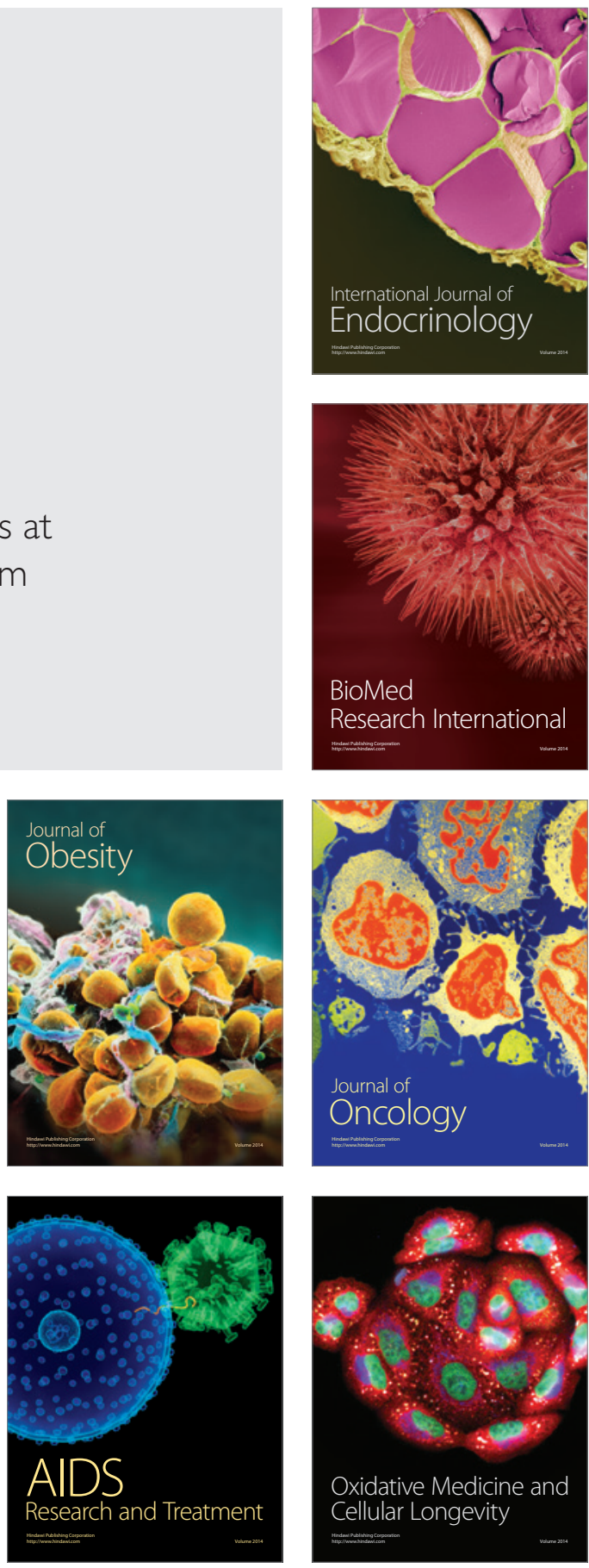